logos_i_ethos_2019_1_(49), s.89-99

DOI: http://dx.doi.org/10.15633/lie.3436

Justyna Stecko

https://orcid.org/0000-0001-9968-7946

Politechnika Rzeszowska

\title{
Applied ethics, i.e. the issue of norms and values in the choices of everyday life
}

\author{
Without the civic morality \\ societies die; \\ Without personal morality \\ they are not worth surviving. \\ (H. E. Fosdick)
}

Nowadays, in social life ethics seems to appear only in moments when topics of great caliber such as abortion, euthanasia or death penalty are discussed. At that time numerous authorities appear in the media that discuss the problem. Ethics, however, is not common in everyday life issues in both aspects of private and professional life. Although in everyday life there are difficult and complicated situations requiring heroism and sacrifice, we are much more likely to face problems of a smaller scale. There are ambiguous situations where one expects a particular position, support for some or disapproval of other behaviors, a moral evaluation of a specific situation, refusal when someone submits immoral proposals or simply "ordinary" honesty. Every day we adhere to the different laws regulating "our being" at home, at work or in the shop, but we do it often mechanically, we do certain orders or we react to bans without thinking about them. The aim of the study is to draw attention to the legitimacy of speaking about ethics in everyday life and reflection on issues related 
to (im)moral choices. In the resolution of these problems concepts such as standards, values, assessments or a wide plane of the distinction between good and evil may be helpful.

\section{The category of good and evil}

In everyday practice we use the common sense distinction of good and evil, unfortunately this border is often moved to areas that would be difficult to call ethical anymore. It seems that the history of reflection on this issue and the establishment of the boundary between the concepts is as long as the functioning of rational beings in the universe. Some attempts to define these concepts are already found in Homer's works and from the stories of gods and heroes one can pick out the advantages important for the ancients like honor, courage but also cunning or friendship. Not only the texts of Greek poets but also great philosophers took up these issues.

In the philosophical tradition the issue of good and evil has appeared many times, and in seeking the answer to the question of how we can define them, we find in the history of philosophical ideas a wealth of different answers. Both ontologically and epistemologically, we can find equally strong definitions, which are often mutually exclusive. From an ontological point of view it seems that at least three different notions are possible, including dualism of beings of good and evil where their status is equally strong and both forces clash with the course of the universe, and only depending on which force in the moment wins, the world appears to us as a creation with a predominance of good or evil. The second concept may indicate the original being of evil where good turns out to be only a secondary category. Evil is ontologically primitive, and if good appears ever in the world it is only because of free rational beings. The last concept is the idea of evil as non-being. Evil does not exist as in itself it is not a character of being and at most it is the cause - like in the previous approach - of a human being. A supporter of this approach was St. Augustine who argued that in reality what we perceive as evil is only a lesser good without which the world would not be as beautiful as it is. 
Reality appears as a work of art where contrasts do not disturb but even make the beauty of the whole visible. Moans caused by suffering do not destroy the ideal symphony of the world. In the discussion of the ontological lack of what evil is supposed to be, Leszek Kołakowski's solutions are close to me. ${ }^{1}$ It is worth quoting the legend of the tyranny of Falarys, which Kołakowski quotes in Polityka i diabet. ${ }^{2}$ According to the tradition, Falarys had a bull with bronze, inside which his opponents were burned alive. The statue was constructed in such a way that thanks to the acoustic device the moans of the victims emerged outside as a pleasant melody. Perhaps our world is such a bull, and the effect, now unimaginable to us, will once appear as a beautiful symphony, but this answer is not only cruel but also unconvincing. As you can see, it is difficult to find an indisputable solution; perhaps it will be easier if we deal with norms and values.

\section{What are norms?}

It seems that we can assume that a habit, a custom and a religion, or broadly understood culture were the first forms of regulation of interpersonal relations, the first codes of conduct of people towards each other. In ordinary terms, a norm is a rule, a recipe. If you look at such statements for example: "Do not lie," "You must not deprive anyone of life," "Every citizen of such and such age is entitled to vote," "We should respect the environment" can be concluded that the statements that they are considered norms have a different form. They can be expressed in the form of a decree, ordering and even an imperative. It seems that they mainly fulfill a duty and a prescriptive function regulating social life. The norms of a custom have had the type of sanctioning of the community's opinion, a direct rigorous regulatory norm whose sanction works quickly. The process of society development involves stretching sanctions

1 J. Stecko, Prywacyjna koncepcja zła w interpretacji Leszka Kołakowskiego, „Humanities and Social Sciences” 18 (2013) no. 20 (1), pp. 97-103.

2 L. Kołakowski, Moje słuszne poglądy na wszystko, Kraków 1999. 
over time. It has become in religious norms ultimately after death, will not pass over anyone and will always be just. In turn, the legal sanction is more immediate, but definitely less fair. Although all these sanctions have a non-marital dimension, they do not exclude the fact that they can overlap and even strengthen each other. At this point we should also mention so often discussed legal norms which regulate in a significant way social life. Ossowska states that such classification is fluent: one and the same norm forbidding us, for example, telling a lie or a deception can be treated as a legal norm, or as a moral norm, depending on the emotion that accompanies it at the moment or also not. ${ }^{3}$ With regard to our subordinates we should act honestly - this is a one-sided order (i.e. a moral norm), while when we consider the requirement of integrity as the right of subordinates who expect it, we are talking about a legal norm. When we talk about norms we should also differentiate between individual norms and those that apply to entire social groups. A man, being a social being, cannot live in isolation from others, and this creates new perspectives (possibilities of being for others and with others), but also new tasks.

The division of norms which could be quoted here is a large amount, but this is not the purpose of this study, the key conclusion seems to be Władysław Witwicki's conclusion, which states: "Moral behavior is just what oil in a social machine. It reduces the inevitable friction and allows the course of social life, without spoiling the social machine. Normative ethics is a rational set of recipes for this lubricant and the provisions of its use." Let's move to the norms that directly point to the ethical area.

\section{Ethical standards}

The singularity of ethical norms is that they are respected regardless of external sanctions and appear to be related to the "moral maturity" of a human being. The motive for ethical conduct is not an external

3 M. Ossowska, Normy moralne. Próba systematyzacji, Warszawa 1985, p. 45.

${ }^{4}$ W. Witwicki, Pogadanki obyczajowe, Warszawa 1957, p. 20. 
reward or punishment, but a value in itself. Ethicists have distinguished many different types of divisions due to various criteria, among others due to their genesis or a scope of application. For the purpose of this study, I would just like to quote the distinction that Maria Ossowska proposed.

These are standards:

- in defense of our biological existence,

- in defense of dignity,

- in defense of independence,

- in defense of privacy.

In addition, there are standards for social relations:

- serving the need for trust,

- guarding justice,

- and mitigating social conflicts.

Ossowska also pointed out meta-norms:

- a rule of principles that says that it is necessary to treat beings belonging to the same category in the same way,

- Kant's imperative,

- the principle of consequences in assessing, and that prohibits treating oneself differently from others,

- a rule that nobody can be both a judge and a party to a given case,

- a rule regulating the scope and conditions of validity of norms. ${ }^{5}$

Unfortunately, there is no universally accepted way to justify moral norms or entire ethical theories. The most important ways of justifying moral norms that can be found in textbooks include the teleologism of Aristotle; the hedonism of epicureans, the perfectionism of the stoics, theistic justifications of ethics, modern theories of natural rights, theories of social contract, Kantism, counter-updating, ethical intuitionism, personalism and various varieties of ethical naturalism. ${ }^{6}$ However, it seems that for the purposes of this study it is enough to indicate only that there is a whole reservoir of different solutions and the problem

5 M. Ossowska, Normy moralne..., op. cit., p. 89.

6 V. J. Bourke, Historia etyki, Torun 1994. 
is not zero-based. The binding of moral values with other values may consist in the fact that moral norms are assigned the task of serving to defend certain goods, such as life, freedom and security. Therefore, the necessary condition for the existence of moral norms is the existence of some goods or we can directly name values.

\section{Axiological awareness and values}

The problem of morality has always been the problem of the subject. Without the subject, morality would be in a vacuum, it would be no man's morality. The moral character of an act is determined by the circumstances and meanings assigned to it by the subject. Movement with the leg can be a banal muscle activity or an action in the ethical sense, it is enough that the person making it consciously wants to hurt or help the other. ${ }^{7}$ Moral awareness is a kind of axiological consciousness which is our sensitivity to any value. So it is this ability that estimates responsibility for the good or evil that we have done to another human being. It is a certain attribute that accompanies a man. The axiological consciousness, due to its phenomenological origin, is based mainly on qualitative methods and will be realized more as an anthology of contributions than hard theory.

Speaking of values, it is impossible not to mention the division of Max Scheler. ${ }^{8}$ He created a hierarchy of values by distinguishing four levels. The principle of this division is such features as: duration, range, independence and depth of satisfaction. By using these criteria he prepared his own hierarchy of values. Sensory values are the lowest, including items of both pleasure and pain, as well as various useful goods. In the second place he set the vital values, such as pros and cons, or a strength and a weakness.

7 Oblicza doświadczenia aksjologicznego. Studia i rozprawy, red. P. Duchliński, G. Hołub, Kraków 2011.

${ }^{8}$ V. J. Bourke, Historia etyki, op. cit., p. 240. 
The next are spiritual values, e.g. knowledge of truth, righteousness and lawlessness. For the highest, he adopted religious values, to which he included happiness and despair, as well as feelings of sanctity and opposition to them. Scheler also pointed out that there were two types of duties: being and acting. The duty of action is based on being, creating together the basis of moral obligation. Moral values, however, are not equivalent to the levels described above. They arise when a person realizes a value from a higher level before a value from a lower level, or submits the former above the other. It follows from this that moral values are personal values, and moral obligation consists in responding to the aforementioned values. ${ }^{9}$ Another representative of contemporary axiological ethics was Nicolai Hartmann. He believes that the values can be learned in an intuitive way using cognitive and emotional acts of consciousness. In his dissertations, he emphasized that the object values were not subjective states of consciousness, nor are they physically existing entities. They are a separate area - an ideal reality. Individuals are more or less open to value experience. The feeling is the most important in the initial opening to values. ${ }^{10}$ By creating a hierarchy of values Hartmann relied heavily on the value of Scheler's, while criticizing his simplification. In contrast, Hartmann believed that higher values were based on lower values, and were even somewhat dependent on them. In the Hartmann's hierarchy of values there are: elementary values, values conditioning the internal content of the subject, e.g. life, suffering, strength and moral values; basic ones such as nobility, good and specific values: wisdom, bravery, justice. This juxtaposition is a complex system of objective criteria for what is valuable. ${ }^{11}$

For a man it should be important to be an evaluating attitude, in fact every act can be subject to moral evaluation. In everyday life we often occupy a particular valuing attitude - something is good and something bad - the choice may assume not only valuation but also hierarchization.

\footnotetext{
9 V. J. Bourke, Historia etyki, op. cit., p. 243.

10 V. J. Bourke, Historia etyki, op. cit., p. 243.

11 V. J. Bourke, Historia etyki, op. cit., p. 243.
} 
Moral judgments, or value judgments refer to human acts. They can be specific (they occur when they express an evaluation of a human act fulfilled in a specific place and time) or general (they adjudicate about the good or moral evil of a specific species specific category of human acts).

According to Maria Gołaszewska the world of axiology is unfortunately not white and black and the choices are not always obvious. What's more, we often encounter a category of greater or lesser good or less or greater evil. There is a "common belief that there is a lesser evil and a greater evil, that certain human behaviors, as well as states of affairs, can be ranked due to the moment of their relationship with certain values - negative and positive ones." 12 "Chessboard" of values is a set of possibilities, it seems, close to their essential properties. There is polarization here: positive values - negative (pendant for white and black figures); and there is no suggestion that any of them have any "privileges" in the system, but they are opposed. There is also a gradation, from the value of "more important," higher, to those whose functions in the anthropist are limited to "one-dimensional" values, with a small range of influence. But what is the most important here is the system of movements, the system of possibilities of mutual influence of values on oneself and on the man whom we place among the highest values. The rules of the game of chess are precise, but at the same time they allow a finite but an uncountable number of moves, combinations, until reaching the situation in which the next move, the next axiological possibility no longer exists." ${ }^{13}$ According to Gołaszewska, not only can we rank good indicating the effects of actions. Since evil can have different degrees of severity, then we can and even should rank its manifestations. Gołaszewska distinguishes several stages of evil: moral indifference, evil project, passive evil, active evil and ambiguous evil. The anthroposphere does not include objective evil, occurring outside the consciousness of the "I" in the form of natural world events. It is not subject to valuation in ethical terms, although it may cause suffering to people and is, therefore, anthropomorphized by the

12 M. Gołaszewska, Fascynacja złem. Eseje z teorii wartości, Warszawa-Kraków 1994, p. 194.

13 M. Gołaszewska, Fascynacja złem, op. cit., s. 194. 
assignment of some axiological qualification. It seems that each of these stages of evil is characteristic of contemporary man.

\section{Conclusions}

Almost the entire history of the philosophy of morality consists in the attempt to find the right pattern for making decisions, judging actions and justifying acts. So what will it be for applied ethics? It seems that it is nothing more than applying certain concepts of normative ethics to concrete, practical ethical problems in order to normalize the consideration of duties or answers about good and evil in specific situations. It seems, however, that the key conclusion here is not the answer to what standards we should act and what values to follow and the reflection on the world of values, choices and assessments in everyday life. An action that is not blind, mindless, or subordinate to the only value that egoistic pleasure currently is. It seems that the ethics of everyday life should be the component that distinguishes the human world. Unfortunately, looking at young Europeans today, it is difficult to be optimistic. In most sociologists' research on honesty, truthfulness, faithfulness and simple decency, respondents choose to live without such rules, treating them as a relic of the past or simply naivety. But what will be the world like where we treat the other person only as a bridge to pleasure, success and egoistical impressions? Is such the world a place where we would like to live? Perhaps a simple Kantian principle would be enough (of course, taking into account the objections connected with it) to treat the other person as we would like to be treated but the key conclusion remains the need to reflect on the ethics of everyday life.

\section{References}

Bourke V. J., Historia etyki, Toruń 1994.

Gołaszewska M., Fascynacja złem. Eseje z teorii wartości, Warszawa-Kraków 1994.

Kołakowski L., Moje słuszne poglądy na wszystko, Kraków 1999. 
Oblicza doświadczenia aksjologicznego. Studia i rozprawy, red. P. Duchliński, G. Hołub, Kraków 2011.

Ossowska M., Normy moralne. Próba systematyzacji, Warszawa 1985.

Stecko J., Prywacyjna koncepcja zła $w$ interpretacji Leszka Kołakowskiego, „Humanities and Social Sciences" 20 (2013) no. 1, s. 97-104.

Witwicki W., Pogadanki obyczajowe, Warszawa 1957.

\section{Abstract \\ Applied ethics, i.e. the issue of norms and values in the choices of everyday life}

Valuation and evaluation are inevitable in life. They concern both making personal choices and assessing facts. In the world where we live, ethics seems to appear only when social issues such as abortion, euthanasia or the death penalty go to the discussion. Ethics, however, is not common in the issues of everyday life, in the choices that accompany us on every level of life. In both private and public life one can notice more and more blind momentum, more and more tasks but also we set the boundary between good and evil with greater difficulty. It seems that the diagnosis regarding the axiological crisis seems more and more accurate today. The common belief that it is allowed to do so because "everyone does it" is nothing more than a mindless imitation of social behavior or just plain ignorance of ethics. According to Seneca the thing which is not prohibited by the law is prohibited by shame, it seems that today the shame, which in this sentence was a synonym of "awareness" or "ethical sensitivity" ceased to exist. The aim of this article is a brief reflection on the ethics of contemporary man, on the way how he makes choices, and actually on the basis of what he should take. The inspiration for writing this text was the author's personal experience, which indicates the lack of optimism in assessing the moral condition of a modern man.

\section{Keywords}

norms, values, axionormative area, ethics of everyday life 


\section{Abstrakt \\ Etyka stosowana czyli zagadnienie norm i wartości w wyborach życia codziennego}

Wartościowanie i ocenianie jest w życiu nieuniknione. Dotyczy ono zarówno dokonywania osobistych wyborów, jak i oceniania faktów. W świecie, w którym przyszło nam żyć, etyka wydaje się pojawiać dopiero w momentach, gdy do dyskusji trafiają istotne tematy społeczne, takie jak aborcja, eutanazja czy kara śmierci. Etyka nie jest jednak powszechna w zagadnieniach życia codziennego, w wyborach, które towarzyszą nam na każdej płaszczyźnie życia. Zarówno w życiu prywatnym, jak i publicznym coraz więcej ślepego pędu, coraz więcej wyznaczamy sobie zadań, ale też z większym trudem wyznaczamy granicę między dobrem i złem. Wydaje się, że współcześnie coraz bardziej trafna wydaje się diagnoza dotycząca kryzysu aksjologicznego. Powszechne przekonanie, że wolno tak robić, ponieważ „wszyscy to robią”, to nic innego, jak bezmyślne naśladowanie zachowań społecznych bądź po prostu zwykła ignorancja wobec etyki. Zdaniem Seneki - czego nie zabrania prawo, zabrania wstyd. Wydaje się, że dzisiaj wstyd, który w tej sentencji był synonimem „świadomości” czy „wrażliwości” etycznej, przestał istnieć. Celem artykułu jest krótka refleksja nad etyką współczesnego człowieka, nad sposobem, w jaki podejmuje wybory, a właściwie w oparciu o co powinien je podejmować. Inspiracją do napisania tego tekstu były osobiste doświadczenia autorki, które wskazują na brak optymizmu w ocenie kondycji moralnej współczesnego człowieka.

\section{Słowa kluczowe}

normy, wartości, płaszczyzna aksjonormatywna, etyka codzienności 